Volume 8 No. 1 April 2021

Nationally Accredited No. 30/E/KPT/2018 Dated 24th October 2018

This work is licensed under a Creative Commons Attribution-NonCommercial 4.0 International License

\title{
The Notion of Divine Principle (Asas Ilahiah) In Indonesian Contract Law
}

\section{Djumikasih*, Thohir Luth, Abdul Rachmad Budiono, Imam Koeswahyono}

Faculty of Law, University of Brawijaya, Jalan Veteran, Malang, Indonesia, 65145

Jalan Veteran, Malang, East Java, Indonesia. 65141.

*E-mail: kimujd@ub.ac.id

Submitted : 2020-11-23 | Accepted : 2021-04-26

\begin{abstract}
This study is legal research aiming to find out the essence of Divine Principles in Indonesian Contract Law from the review of the Natural Law theory, the Sunt-Servanda theory, the Awareness and Legal Obedience Grundnorm theory, and Truth theory. This research reveals that the Divine Principle's essence is the most fundamental principle or guideline derived from God but exists in humans, aiming to find the truth and regulate the parties in making agreements. The application of the Divine Principle aims to find the truth and regulate the parties in the agreement's field. Indonesian citizens could realize and practice the Precepts of Godhead in their agreement activities. In establishing the agreement, the parties are applying the teachings of their respective religions. This study reveals that the Divine principle needs to be incorporated into one of the upcoming National Agreement Laws principles, especially in the contract born because of the agreement. This study maintains that the divine principle can be applied comprehensively for Indonesian citizens who are parties to the agreement, not only limited to the Indonesian Muslim citizens.
\end{abstract}

Keywords: $\quad$ Divine Principle or Ilahiah principle, Contract Law

\section{INTRODUCTION}

Indonesia does not yet have a National Agreement Law product from the Indonesian people themselves, so pluralism still occurs in treaty law in force in Indonesia. Indonesia still applies treaty law in Dutch civil law, Indonesia customary law, and Islamic treaty law. This pluralistic system causes many problems for law enforcement because it can lead to legal uncertainty for Indonesia citizen and population. Legal certainty is legal protection against arbitrary actions. ${ }^{1}$

The formation of national treaty law guarantees legal certainty in treaty law and becomes national pride because Indonesia can make its laws. To establish national treaty law, it is necessary to study the legal principles in the three existing treaty legal

1 Prof. Dr. Sudikno Mertokusumo, S.H.. (1999). Mengenal Hukum Suatu Pengantar. (Yogyakarta, Liberty Yogyakarta, Ed.4; Cet.2, 1999) 
systems in Indonesia as the basis for establishing national treaty law first. Indonesia, as a nation, has an identity that must be realized in its legal system. The wealth of life values and the philosophical foundation as an independent nation must be explored to become the foundation for the Formation of the National Engagement Law. The factual habits that have taken root and the Indonesian people's religious principles must be considered in shaping national treaty law without neglecting attention to international developments. ${ }^{2}$

The legal system of treaties in force in Indonesia has the same legal principles even though the mention is different, such as the principle of consensual and the principle of habit. This principle is in the Civil Code, Customary Law, and Islamic Law. There are also legal principles that are only found in one legal system and are not found in the other two legal systems, namely the divine principle, which is only found in the legal system of Islamic agreements.

The Divine Principle or the Principle of Monotheism is the principle of Islamic treaty law, which states that every human behavior and deed is always seen and monitored by Allah SWT. Although not yet fully, the Sharia principle has been concretely used in Islamic institutions like in the banking environment. This fact can be used as an embryo to adopt sharia principles in the development of Indonesian National Law. All parties could apply state law without questioning its source; therefore, the facts can ward off all types of prejudice and instead foster national commitment to always compromise for the formation of a national system law with a national identity.

2 Isnaeni, Moch..Hukum Perkawinan Indonesia / Moch. Isnaeni. 2016

3 Prof. Jawahir Thontowi, Pancasila dalam

Prespektif Hukum Pandangan Terhadap
In Indonesia, Pancasila is the source of all legal sources. It means that all sources of law or regulation (i.e., TAP MPR, Law, PERPU, Government Regulations, Presidential Decrees, Local Government Regulations (Province level or City/district level) and all implementing regulations) must stand on Pancasila as its legal basis. All legal products must comply with Pancasila and must not deviate from them. As a source of positive law in Indonesia, Pancasila contains the intention that although Pancasila's values are proven to be universally valid, formally, Pancasila only applies as a source of all sources of law that exist in the Indonesian legal system. Pancasila as the source of all positive sources of law in Indonesia means that the position of Pancasila, in this case, makes the guidelines and direction for every Indonesian nation in developing and improving the legal conditions in Indonesia. ${ }^{3}$ Therefore, it can be concluded that the founder of Indonesia hopes that all life as a nation and state, including the life of the law, more specifically the law of agreement, prioritizes the principle of divinity. Therefore, it is very important to adopt the Divine principles in the Islamic Agreement Law, to be realized and confirmed as one of the principles in the upcoming Indonesian National Agreement Law. Therefore, to realize the divine principle in the coming Indonesian national treaty law, it is necessary to examine in advance what is the nature or essence or the actual basis of the Divine principle. From the background of the problems mentioned above, it is necessary to research the Divine principle's nature in contract law?

\footnotetext{
Ancaman "The Lost Generation", (UII Press, Jogjakarta, 2016)
} 


\section{LEGAL MATERIALS AND METHODS}

The type of research applied in this article is normative legal research. This study examines and examines one of the principles of contract law originating from Islamic covenant law, namely the divine principle, to discover its essence, urgency, and realization to govern future national contract laws. The approach method used in this research is the statute approach, especially the following seven laws and several articles from the Third Book of the Civil Code on Engagement.

1. Law of the Republic of Indonesia No. 30 of 2004 concerning the Position of Notary and Law of the Republic of Indonesia No. 2 of 2014 concerning Amendments to Law of the Republic of Indonesia No. 30 of 2004 concerning the Position of Notary

2. Law of the Republic of Indonesia No. 21 of 2008 concerning Sharia Banking,

3. Law of the Republic of Indonesia No. 4 of 1996 concerning Mortgage Rights to Land and Objects Related to Land,

4. Law of the Republic of Indonesia No. 42 of 1999 concerning Fiducia Guarantee and

5. Law of the Republic of Indonesia No. 13 of 2003 concerning Manpower.

6. Law of the Republic of Indonesia Number 23 of 2011 concerning Management of Zakat

7. Law of the Republic of Indonesia Number 41 of 2004 concerning Waqf.

Legal materials in this study consist of primary legal materials, secondary legal materials, and tertiary legal materials. Primary legal materials consist of various

4 David P. Weber, 'Restricting the Freedom of Contract: A Fundamental Prohibition'99999999, provisions regarding agreements both in the third book of the Civil Code concerning Engagement and several national product laws relating to agreements. Secondary legal materials consist of legal materials that provide explanations for primary legal materials, in the form of doctrines and scientific works on the principles of contract law, especially on divine principles. Tertiary legal materials consist of legal materials that provide explanations for primary and secondary legal materials, such as an English dictionary, a Dutch dictionary, an Arabic dictionary, a legal dictionary, and an Indonesian dictionary.

Moreover, the analysis technique used in this research is the grammatical interpretation technique using the induction method, in this case, the divine principle, which is regulated explicitly in Islamic contract law, then it is drawn into something general in nature, which is one of the applicable principles in national contract law.

\section{RESULT AND DISCUSSION}

In the Indonesian Civil Code (Kitab undang-undang Hukum Perdata) Book III, there are several principles of agreement law, including the principle of freedom of contract, consensual principle, legal certainty (pacta sunt servanda), and the principle of good faith, and the principle of personality (personality). The following is an explanation of the principles referred to:

\section{a. Freedom of Contract}

The freedom of contract is general rights of an individual to create a contract. ${ }^{4}$ However, there are some limitation such as age, purpose and object of the contract, and etc. 
The principle of freedom of contract can be analyzed from the provisions of Article 1338 paragraph (1) of the Civil Code, which reads: "All agreements made legally are valid as laws for those who make them."

This principle is a principle that gives the parties the freedom to:

1. Make or not make an agreement

2. Enter into an agreement with anyone

3. Determine the contents of the agreement, its implementation, and requirements

4. Determine the form of the agreement, whether written or oral

However, as stated before even if the principle called freedom of contract but there is some limitation. The limitation is used to protect both of the parties.

\section{b. Principle of Consensualism (Concensualism)}

The principle of consensual can be concluded in Article 1320 paragraph (1) of the Civil Code. In this article, it is determined that one of the conditions for the agreement's validity is the existence of a word of agreement between the two parties. Every agreement must be based on a consensus. It does not have to be formally held but sufficiently agreed by both parties. An agreement is an agreement or meeting of will between the parties at the same point.

\section{c. The Principle of Legal Certainty (Pacta sunt servanda)}

The principle of legal certainty, also known as the pacta sunt servanda principle, is a principle related to the consequences of the agreement. The principle is basic and it universally accepted as one of the contract law principle. ${ }^{5}$

5 Hayland Richard, Pacta Sunt Servanda: 'A Meditation', (1994) 34, Virginia Journal of International Law, p.406
The principle of pacta sunt servanda is that judges or third parties must respect the substance of the contract made by the parties, as befits a law (as long as the object or purpose of the contract legal). They may not intervene in the substance of the contract made by the parties. The principle of pacta sunt servanda can be concluded in Article 1338 paragraph (1) of the Civil Code.

\section{d. The Principle of Good Faith (Good Faith)}

The good faith principle is one of the key concept in civil law system. ${ }^{6}$ This principle provides protection for each of the party interest.

In Indonesia, the principle of good faith is contained in Article 1338 paragraph (3) of the Indonesia Civil Code, which reads: "The agreement must be carried out in good faith." This principle is the principle that the parties, namely the creditor and the debtor, must carry out the substance of the contract based on firm belief and the goodwill of the parties. The principle of good faith is divided into two types, namely subjective good faith and objective good faith. In the first intention, someone pays attention to the real attitude and behavior of the subject. In the second intention, the assessment lies in common sense and fairness, and an objective measure is made to assess the situation (an impartial assessment) according to objective norms.

\section{e. Personality Principles (Personality)}

The principle of personality is a principle that determines that someone will perform and/or make a contract only for the benefit of that person. This can be seen in Article 1315 and Article 1340 of the Civil

6 Ejan Mackaay, 'Good Faith in Civil Law Systems:
A Legal-Economic analysis', (2012) 18, Revista
Chilena de Derecho Privado, p.149 
Code of Indonesia. Article 1315 of the Civil Code states: "In general, a person cannot enter into an engagement or agreement other than for himself." Article 1340 of the Civil Code reads: "The agreement is only valid between the parties who made it." It means that the agreement made by the parties only applies to them, does not apply to other people.

However, there are exceptions to this provision, namely as stipulated in Article 1317 of the Civil Code, which states: "An agreement can also be made for the benefit of a third party, if an agreement made for oneself, or a gift to another person, contains such a condition."

This article regulates that a person can enter into a contract for the benefit of a third party, provided that there are certain conditions. In comparison, Article 1318 of the Civil code does not only regulate agreements for oneself but also for the interests of their heirs and for people who obtain rights thereof. If the two articles are compared, Article 1317 Indonesian Civil Code regulates agreements for third parties, while Article 1318 Indonesian Civil Code is for the interests of themselves, their heirs, and people who obtain rights from those who make them. Thus, Article 1317 Indonesian Civil Code regulates the exemption, while Article 1318 Indonesian Civil Code extends its validity.

In addition to the principles described above, in the Engagement Law Workshop organized by the National Law Development Agency (BPHN), the Ministry of Justice of the Republic of Indonesia on 17-19 December 1985 succeeded in formulating eight principles of national engagement law, namely as follows:

a. Principle of Trust
The principle of trust implies that everyone who will enter into an agreement believes that the parties will fulfill every achievement made between them in the past.

b. Principle of Legal Equations

The principle of equality of law implies that the legal subject who enters into an agreement has the same position, rights, and obligations in law. They must not be distinguished from one another, even though the legal subjects have different skin color, religion, and race.

c. Principle of Balance

The principle of balance is the principle that requires both parties to fulfill and carry out the agreement. The creditor has the power to demand achievement and, if necessary, can demand the repayment of the achievement through the debtor's wealth. However, the debtor also bears the obligation to carry out the agreement in good faith.

d. The Principle of Legal Certainty

The agreement as a legal figure contains legal certainty. This certainty is revealed from the binding strength of the agreement, namely as a law for those who make it.

e. Principle of Morality

This moral principle is bound in a fair engagement, which is a voluntary act from a person who cannot claim the right for him to challenge the debtor's performance. It can be seen in zaakwarneming, which is someone doing actions voluntarily (morally). The person concerned has a legal obligation to continue and complete his actions. One factor motivating the person concerned to commit such legal acts is based on morality as a calling to his conscience.

1. Principle of Compliance 
This principle relates to the provisions regarding the agreement's contents, which are required by appropriateness based on the nature of the agreement.

2. The principle of habit

This principle is seen as part of the agreement. An agreement is binding for what is expressly regulated and for things that are generally followed.

\section{Principle of Protection}

The principle of protection implies that the debtor and creditor must be protected by law. However, it is the debtor who needs to receive protection because this party is in a weak position. These principles form the basis of the parties in determining and making a contract in their daily legal activities. Thus it can be understood that the broad principles above are essential and absolutely must be considered for the contract maker so that the final goal of an agreement can be achieved and carried out as desired by the parties.

Although a national engagement law workshop had been conducted, which resulted in the principles of national engagement law, the divine principle was not included in the results of the workshop. This is understandable because the workshop has been going on for a long time, about 30 years ago, even though the development of treaty law, especially Islamic law, has been very rapid in Indonesia recently. Therefore, it is essential to include the divine principle in the law of future national covenants. The next section of this article will discuss the Divine Principle from several theories.

\section{The review of Divine Principles from} Natural Law Theory

Natural law is the legal norm that is supra positive, unchanging, universal, and automatically applies and possibly natural rights with correlated obligations based on the natural order created by God or not. Natural Law Laws could be described by humans a priori of Tatakodrati with the help of natural reason. ${ }^{7}$ Natural law arises from the desire to perfect the positive law, which is imperfect, flawed, and inadequate as a picture of a noble, high, and perfect law. Natural law developed because of the urge to unite positive laws that differed according to regions, countries, and different times. Some opinions about the effect or the relationship between natural law and positive law: some believe that natural law is a positive law, ius constitutum, some believe that natural law is an ideal law, a measure for positive law, an ius constituendum, some are argued, that natural law breaks positive law. So natural law competes with positive law.

From Greek and Roman culture, natural law spread into the medieval culture through its most significant carrier and developer, namely Thomas Aquinas (12241274). Thomas believes Lex Aeterna / Eternal Law is God's law to govern the entire universe. Lex Aeterna comes from God's intellect and is launched for the good of all creatures, humankind, and nature as a whole. Especially for humans, for the sake of eternal truth, it is revealed to humans Lex Divina (part of Lex Aeterna), which is notified through a statement (open baring) in the word of God. Besides that, there is natural law (ius naturale), part of the Lex Aeternae, where humans take part as beings endowed with reason. Natural law is the basis and guidance

Perbankan Syari'ah di Indonesia, (Universitas Diponegoro, 2013)

7 Ja'far Baehaqi, Dialektika Hukum Islam dan Hukum Nasional dalam Formulasi Hukum 152 | Djumikasih, Luth, Budiono, Koeswahyono - The Notion of Divine Principle (Asas Ilahiah)... 
for positive law, which derives from natural law.

Natural law cannot be used as a competitor to positive law; natural law embodies the critical normative idea of positive law (Brunner). The critical content of natural law is justice. Humans have the same existence towards Allah. Each human being is responsible to Allah. Besides that, humans also have different positions and functions in society. According to Brunner, the freedom to exercise the recognition of belief, the right to life and body (against slavery), the right to private property, the right to work, the right to study, and education. The rights of freedom by Brunner are distinguished from human rights. The right to freedom is the right of birth, attached to an individual under any circumstances that should be protected.

In terms of natural law theory, the divine principle includes Lex Divina, which is God's statement outlined in God's word, regulating human life. In Islamic law, the Divine principle has been used as one of the principles in Islamic engagement law; this means that in Islamic engagement law, the Divine principle has become lex naturale / ius naturale. If later, the Divine principle is included in the national engagement law, then the Divine principle will also become Lex Positiva.

\section{The review of Divine Principles from Sunt-Servanda Pact}

Pacta Sunt Servanda means that the contract is binding. ${ }^{8}$ This theory originates and develops in the legal tradition of Continental Europe, mentioned that a contract is made legally and following

8 Davison-Vecchione, D. 'Beyond the Forms of Faith: Pacta Sunt Servanda and Loyalty'. (2015) 16(5) German Law Journal, 1163-1190. applicable law, and is also following custom and feasibility so that it is assumed to be a contract made in good faith. The clause of the clause in such a contract binds the parties that make it, where the power of binding is equivalent to the power of binding law. Therefore, the contract's performance must not be detrimental to either the counterparty to the contract or a third party outside the parties to the contract.

The theory of Sunt Servanda means that a contract binds the parties making it, and binding it is equal to the strength of a law made by the parliament and the government. Sunt Servanda Pactacts as a fundamental theory (grand theory) because it requires various interpretations and adjustments and is varied when manifested in practice. ${ }^{9}$

Major religions always emphasize the importance of obeying what has been promised. That promise must be kept. Religion is the most critical factor in maintaining human dignity and holiness. This elevation of human dignity is the goal of every religion. As a result, no religion considers the bondage of a contract lonely. All of them suggested that the contract be kept because the promise was sacred. Hinduism gives the doctrine to its adherents that fulfilling what has been promised is not a light obligation because defaulting on it can be a sin and will receive substantial rewards in the hereafter. Brihaspati reminded that people who do not keep their promises to pay their debts would be born in the creditor's house as slaves, single, a woman, or a fourlegged animal. Narada said that all obedience belongs to his creditors. In short, not paying a debt is considered holding other people's

9 Dr. Munir Fuady, S.H., M.H., LL.M.. Teori teori Besar (Grand Theory) dalam Hukum, (Kencana, Jakarta, 2014) 
property for the debtor's benefit so that the debtor is equated with a thief.

Christianity and Islam also give a place of honor to the position of a contract. According to Islam, breaking a promise is considered a sign of hypocrites. Christianity also upholds a contract's attachment, including the obligation to keep the contract even though it is made with the enemy. Prophet Muhammad made a contract with the enemies led by Abu Lahab and Abu Jahl, which is known as the Hudaibiyah agreement. Likewise, when the prophet Muhammad made a contract with the enemy, namely the Jews in Medina, which became known as the Medina Treaty. In Judaism, the command to keep promises is also mentioned repeatedly in various books.

Divine principles include the obligation to obey agreements based on one's God's faith, not just obey His commands. Therefore, it is the legal subject's spirituality that feels that it is always being watched by God, which causes him to fulfill the covenant.

In this regard, if the Divine principle is examined from the Pacta Sunt Servanda theory, it can be concluded that the Divine principle is in line with the Pacta Sunt Servanda theory, even the Divine principle is higher than the Pacta Sunt Servanda theory. The principle of Divine is in line with the Pacta Sunt Servanda theory because they both State that the agreement made legally must be kept. Meanwhile, the reason why the authors consider that the Divine principle is higher than the Pacta Sunt Servanda theory is that based on Pacta Sunt Servanda theory, a person is obliged to keep or carry out the agreement because the agreement made legally applies as law for the parties. The agreement, therefore, must be carried out in good faith and cannot be canceled unilaterally. In its development, as written by Achmadi Miru as mentioned above, the principle of Pacta Sunt Servanda is also closely related to the principle of good faith and the conditions of causa, which are lawful for the validity of an agreement. Based on the two jurisprudences mentioned above, it can be seen that the application of the Pacta Sunt Servada principle can be limited if it turns out that at the time of agreeing, there is bad faith or bad faith from one of the parties.

The principle of good faith in making the agreement is closely related to discussing the agreement's validity, particularly regarding the terms of the legal cause. So far, the causa requirement, which is lawful here, means that for the validity of the agreement, one of the conditions is that the agreement must not be contrary to law, public order, and morality, or propriety. According to the Supreme Court decision above, the absence of good faith at the time of agreeing was considered contrary to propriety or morality, so the agreement had to be revised from the prior interest of $5 \%$ per month to $2 \%$ per month. If we want to be consistent, an agreement that at the time of its creation does not meet a legal cause's requirements. As a result, the agreement is null and void, which means that the agreement is invalid, and it is assumed that there was never an agreement from the beginning. If the agreement is not valid, then the Pacta Sunt Servanda principle should also not be implemented.

Regarding the divine principle, if we are consistent that our State's basis is Pancasila and the first precept of the Almighty Godhead, this Divine element should also be included in our contract law. One way to include the element of Divinity in the rules regarding the validity of the agreement is to add that the lawful causes which have been interpreted so far only mean 
that the agreement made cannot be contrary to law, public order, propriety/morality alone, added to the rules that the agreement is made. What is made must also not conflict with the religious teachings of the parties to the agreement. It must be so because to ground Pancasila, the precepts in Pancasila must also be implemented in the real life of the people, not only as a slogan or just memorization, including in the life of contract law.

This divine principle has a more significant position/influence than the Pacta Sunt Servanda principle/theory because the Pacta Sunt Servanda principle states that an agreement made legally applies as law for the parties, so it must be carried out in good faith. So a person's obedience in fulfilling the agreement according to the Pacta Sunt Servanda principle is based on something outside himself, namely the "law," while based on the divine principle, one's obedience to fulfill the agreement comes from within the person concerned, namely his faith in God and his religious teachings.

The review of Divine Principles form Consciousness and Law Obedience Theory

There are two kinds of legal consciousness: positive law awareness (identical to law obedience) and negative law awareness (identical to law disobedience). Various literature explained that a person obeys the law or does not break the law, apart from being a deterrent factor or fear after witnessing or considering the possibility of sanctions being imposed on him if he does not obey the law, due to pressure from other individuals or group pressure. If a role model strongly opposes any act that violates the law, it will prevent someone from breaking the law. It is also possible that an individual decides to obey the rule of law for personal moral reasons. On the other hand, other individuals may decide to disobey the law, also for moral reasons.

The divine principle is included in the third type of obedience, namely internalization. If someone obeys a rule, it is true because he/she feels that the rule is following the intrinsic value he/she adheres. Suppose this divine principle is included in the law of agreement. In that case, it will increase Indonesian citizens' faith in their God and carry out their respective religions' teachings. The practice of the precepts of Almighty God can truly be realized, especially in agreements.

\section{Review of Divine Principles in terms of Natural Law Theory}

Natural law is the whole legal norm that is supra positive, unchanging, and universal. It automatically applies and perhaps natural rights with correlated obligations based on the natural order created by God or not, which laws and natural rights can be described by humans a priori from tatakodrati with the help of natural reason (Notohamidjojo, 1975). The idea of natural law arises from the desire to perfect the positive law, which is imperfect, flawed, and inadequate as a picture of a noble, high and perfect law. Natural law develops because of the urge to unite favorable laws that differ according to regions, countries, and times.

Some opinions about the influence or, more precisely, the relationship between natural law and positive law: some believe that natural law is a positive law, ius constitutum, some believe that natural law is an ideal law, a measure of positive law, an ius constituendum, some are argued, that natural law breaks positive law. So natural law competes with positive law. From Greek and 
Roman culture, natural law spread into the medieval culture through its most significant carrier and developer, namely Thomas Aquinas (1224- 1274). Thomas believes Lex Aeterna / Eternal Law is God's law to govern the entire universe. Lex Aeterna comes from the mind of God and is launched for the good of all creatures, humankind, and nature as a whole system. Especially for humans, for the sake of eternal truth, it is revealed to humans Lex Divina, which is part of Lex Aeterna, which is notified through a statement (open baring) in the word of God. Besides that, there is natural law (ius naturale), a part of Lex Aeternae where humans take part as beings endowed with reason. Natural law is the basis and guideline for positive law, which is the derivation and determination of natural law.

Natural law should not be used as a competitor to positive law. Natural law embodies the critical normative idea of positive law (Brunner). The critical content of natural law is justice. Humans have the same existence towards Allah, and each human being is responsible to Allah. Besides that, humans also have different positions and functions in society. According to Brunner, the freedom to exercise the recognition of belief, the right to life and body (against slavery), the right to private property, the right to work, the right to study, and education. The rights of freedom by Brunner are distinguished from human rights. The right to freedom is the right of birth that under any circumstances is attached to an individual and should be protected according to society.

It could be concluded from the theory of natural law that the divine principle includes Lex Divina, namely God's statement as outlined in God's word, which aims to regulate human life. In Islamic law, the
Ilahiyah principle has been used as one of the principles in Islamic engagement law. It means that in Islamic engagement law, the Ilahiyah principle has become lex naturale / ius naturale. If the Ilahiyah principle is later included in the national engagement law, then the Ilahiyah principle will also become Lex Positiva.

\section{The Review of Divine Principles from Grundnorm Theory}

Grundnorm is the most fundamental rule of law about human life; on top of this basic norm, other more concrete and more specific legal rules are made. Usually, the basic norms that apply in a country are written in the Constitution of that State. According to Hans Kelsen, every country's law must come from a fundamental law, namely the Constitution.

For the Indonesian context itself, the Grundnorm is Pancasila, which is contained in the Preamble of the 1945 Constitution, which is based on the State, the philosophy of life of the nation / the nation's soul, and the source of all sources of law in Indonesia. Therefore, all existing laws in Indonesia must be based on and originate from Pancasila. Especially the first principle of "God Almighty" in Pancasila, including incorporating divine principles in the upcoming Indonesian National Agreement Law.

The Divine Principle, when examined from the Grundnorm Theory, is a source as well as an implementation of Grundnorm itself. Divine principles, which are teachings from God, are said to be the source of Grundnorm because Grundnorm is the most fundamental rule of law about human life where on top of these basic norms, other more concrete and more specific legal rules are made. So, the highest or most 
fundamental rules come from God and Natural Law Theory; they are only described in more specific rules.

Particularly for the Indonesian context, the Grundnorm is Pancasila, where the first precept is Almighty Godliness. Suppose we include the Divine Principle in the law of our upcoming National agreement. In that case, it means implementing the precepts of God Almighty in the real life of the Indonesian people through regulations in the field of treaty law.

\section{CONCLUSION}

In Summary, it can be concluded that the essence of Divine Principles is a principle or guideline that is the most fundamental and influential aspect that comes from God but exists in humankind. from the analysis of the above theories Natural Law Theory, Pacta Sunt Servanda Theory, Consciousness and Legal Obedience Theory, Grundnorm Theory, and Theory of Truth, The Divine principle aims to seek the truth and regulate the parties in the field of contract law. The parties that making and implementing agreements following their respective religious teachings can benefit and not harm, both for themselves and others so that Indonesian citizens can realize and practice the Only Divine Precepts in their real daily activities in the field of contract law. This study result shows that it is fundamental that the Divine principle needs to be included as one of the principles of the upcoming Indonesian National Agreement Law. Especially to the contract born because of the agreement. The divine principle in the Agreement Law can be applied for Indonesian citizens who are parties to the agreement, not only limited to the Indonesian Muslim citizen.

\section{REFERENCES}

\section{Book}

Agus, Bustanudin, Integrasi Sains dan Agama Tinjauan Filsafat Ilmu Kontemporer, (UI Press, Jakarta, 2013)

Baehaqi, Ja'far, Dialektika Hukum Islam dan Hukum Nasional dalam Formulasi Hukum Perbankan Syari'ah di Indonesia, (Universitas Diponegoro, 2013)

Djuhairi, Achmad, Kebebasan Berkontrak Dalam Pandangan Hukum Pejanjian Islam, (Surabaya: Mitra Ilmu, 2008)

Fuady, Munir, Teori teori Besar (Grand Theory) dalam Hukum, (Kencana, Jakarta, 2014)

Hartono, Branto. Prinsip Ut Most Good Faith dalam Pelaksanaan Perjanjian, (Tesis Semarang Pasca Sarjana, Undip, 2015)

Hamdani, Birokrasi Ilahiah, Kekuatan tak terbatas dengan mengenal Allah, (Arga Publishing, Jakarta, 2008)

Hasan, M.Ali, Berbagai Macam Transaksi dalam Islam, (Jakarta: PT. Raja Grafindo Persada, 2003)

Rasjidi, Lili and Rasjidi, Liza Sonia, Dasar Dasar Filasafat dan Teori Hukum, (Citra Aditya Bhakti, Bandung, 2012)

Thontowi, Jawahir, Pancasila dalam Prespektif Hukum Pandangan Terhadap Ancaman "The Lost Generation”, (UII Press, Jogjakarta, 2016)

Mardani, Hukum Perikatan Syariah di Indonesia, (Sinar Grafika, Jakarta, 2013)

Mertokusumo, Sudikno, Mengenal Hukum Suatu Pengantar. (Yogyakarta, Liberty Yogyakarta, Ed.4; Cet.2, 1999) 


\section{Journals}

Davison-Vecchione, D. 'Beyond the Forms of Faith: Pacta Sunt Servanda and Loyalty'. (2015) 16(5) German Law Journal, 1163-1190.

Eisenberg, Melvin A., 'Actual and Virtual Specific Performance, the Theory of Efficient Breach, and the Indifference Principle in Contract Law' (2005) 93(4) California Law Review, 2005.

Huda, Nurul, 'Asas Kebebasan Berkontrak

Dalam Hukum Perjanjian Islam', (2005) XVII(2/November) SUHUF, Fakultas Agama Islam Universitas Muhammadiyah, Surakarta, 2005.

Lukashuk, I. 'The Principle Pacta Sunt

Servanda and the Nature of Obligation Under International Law'. (1989)

83(3). American Journal of

International Law.

Mackaay, Ejan, 'Good Faith in Civil Law

Systems: A Legal-Economic analysis', (2012) 18, Revista Chilena de Derecho Privado

Qonita, Nuha., 'Positioning Islamic Legal

Theory in The Development of Islamic Finance', (2019) 10(1) Jurisdictie: Jurnal Hukum Dan Syariah.

Richard, Hayland, 'Pacta Sunt Servanda: A Meditation', (1994) 34, Virginia Journal of International Law

Suherman, Ade Maman, 'Perdagangan Bebas (Free Trade) dalam Perspektif Keadilan Internasional', (2008) 5(2 January) Indonesian Journal of International Law.
Xavier, Grace, 'Global Harmonization of Contract Laws Fact, or Fiction?' (2004) 20(1) Construction Law Journal.

Weber, David P., 'Restricting the Freedom of Contract: A Fundamental Prohibition', 2013, 16(1), Yale Human Rights and Development Law Journal

\section{Regulations}

Law of the Republic of Indonesia No. 30 of 2004 concerning the Position of Notary and Law of the Republic of Indonesia No. 2 of 2014 concerning Amendments to Law of the Republic of Indonesia No. 30 of 2004 concerning the Position of Notary

Law of the Republic of Indonesia No. 21 of 2008 concerning Sharia Banking,

Law of the Republic of Indonesia No. 4 of 1996 concerning Mortgage Rights to Land and Objects Related to Land,

Law of the Republic of Indonesia No. 42 of 1999 concerning Fiducia Guarantee and

Law of the Republic of Indonesia No. 13 of 2003 concerning Manpower.

Law of the Republic of Indonesia Number 23 of 2011 concerning Management of Zakat

Law of the Republic of Indonesia Number 41 of 2004 concerning Waqf. 